\title{
SIMPLE STRATEGIC ANALYSIS TOOLS AT SMES IN ECUADOR
}

\author{
MBA. Diego H. Álvarez Peralta \\ Universidad de Palermo, UP, Argentina \\ E-mail: dalvarezperalta77@gmail.com \\ Dr. Leandro A. Viltard \\ Pontificia Universidad Católica Argentina, Argentina \\ Universidad de Palermo, Argentina \\ E-mail: Iviltard@yahoo.com.ar \\ Submission: $12 / 01 / 2015$ \\ Revision: 26/01/2015 \\ Accept: 30/01/2015
}

\section{ABSTRACT}

This article explores the possible applications of Strategic Analysis Tools (SAT) in SMEs ${ }^{1}$ located in emerging countries such as Ecuador (where there are no formal studies on the subject). It is intended to analyze if whether or not it is feasible to effectively apply a set of proposed tools to guide mental map decisions of executives when decisions on strategy have to be made. Through an in-depth review of the state of the art in regards to SAT and interviews performed to main participants such as chambers and executives of different firms, it is shown the feasibility of their application. This analysis is complemented with specialists' interviews to deepen our insights and obtaining valid conclusions. Our conclusion is that SMEs can smoothly develop and apply an appropriate set of SAT when opting for very relevant choices. However, there are some inconveniences to be solved which are connected with resources (such as peoples' abilities and technology) and behavioral (cultural factors and methodological processes). Once these barriers are knocked down, it would be more likely to enrich current approaches to make strategic decisions even more effective. This is a qualitative investigation and

${ }^{1}$ SMEs stands for Small and Medium-sized Enterprises. Factors such as the number of employees and turnover are basically considered to define them in regions across the globe. In Mercosur, firms are categorized as SMEs if they have up to 300 employees or if they gross up to US\$10 million in revenues. 
INDEPENDENT JOURNAL OF MANAGEMENT \& PRODUCTION (IJM\&P)

http://www.ijmp.jor.br

v. 6, n. 2, April - June 2015

ISSN: 2236-269X

DOI: $10.14807 /$ ijmp. v6i2.289

and the research design is not experimental (among them it is transversal as it relates to a specific moment in time)..

Keywords: Strategic analysis tools; SME; Formulation; Competitiveness; context assessment; value.

\section{DESIGN: METHODOLOGY AND ANALYSIS}

Our methodology is qualitative and explores information gathered in a specific period of time (the last quarter of 2013 up to October 2014).

The analysis unit included the SMEs established in Quito, Ecuador.

In this paper, we will concentrate on state of the art theories about best suitable tools suggested for SMEs, the results of interviews to key contributors and a brief analysis of a representative SME located in Quito, Ecuador.

As a consequence we made three interviews to local prestigious consultants and scholars who are based in Quito, Ecuador. These interviews were held in order to compare the hypothesis and objectives with the experience of the experts.

In order to obtain quality assurance, a case analysis of Indulentes (a top SME publicly known and acknowledged by specialized magazines) is presented. Being the minimum analysis unit, it introduces favorable characteristics to contrast advantages and limitations of using the SAT proposed by theorists with the reality of a business that possesses the necessary resources to afford their application. In this way, this SME would apply any tools from the elementary level to more complexes, and by means of them exploiting the necessary wisdom to strengthening its competitive position.

\section{RESEARCH LIMITATIONS/CLARIFICATIONS}

- Although we are aware that it is unlikely to ascertain that all relevant information has been included, we referred to worldwide information obtained from relevant secondary sources.

- The information provided by the principals of the respective Chamber was the best we could access because of confidential matters. 
- The interviews with key specialists and the Chamber's principals were held in their offices to minimize the impact on their environment, and on the results as well. We used semi-structured interviews in order to enrich, as much as possible, this investigation's outcome.

- In order to not undermine the content and the investigation's objective, the conclusions and contributions expressed were strictly based on the information and first-hand collected data.

As a qualitative research, results shown cannot be generalized. However, they are useful for decision making purposes for a wide audience such as government, non-government organizations, business managers, academics and consultants. Our aim is to enhance comprehension on how to apply methodologically strategic analysis tools to provide better insight and making optimal choices.

\section{FINDINGS}

By clearing cultural barriers and leveraging the right's executive's mentality, the application of strategic analysis tools is feasible in an emerging country such as Ecuador. The content and scope of applying them can be continuously improved by defining appropriate processes and paths that can lead to produce approaches to be upgraded from time to time.

\section{ORIGINALITY AND VALUE}

Despite the fact that economic contribution of the SMEs in the Ecuadorian economy has been researched, we realized that there are not studies on the utilization or direct application of the strategic analysis tools from a managerial perspective.

We trust that this study can help in either designing or improving policies in regard to improving the formulation of strategies in these firms. Implications to this paper can refer to a wide basis, from the micro level -when executives select choices- to the macro level, when government or non-government organizations prepare plans to support these firms. 


\section{OBJECTIVE OF THIS INVESTIGATION}

To research the state of the art concerning strategic analysis tools applicable to SMEs especially for firms of emerging markets such as Ecuador and make a value added proposition of specific set of tools applicable when formulating strategy at firm level.

\section{INTRODUCTION}

Despite the large economic contribution of SMEs in emerging market countries, there is little research on tools aimed at either measuring or improving their internal competitiveness.

It seems that governments in some circumstances have assigned resources to researching on how to increase competitiveness in key sectors of the economy. However, the positive outcome that may be obtained of those projects has been barely visible. This phenomenon may be explained because of the lack of connection between the political vision and strategic objectives that respective SME' executives may have formulated. At the firm level, managers develop the strategic vision either sometimes in house or with any occasional help of outsiders, and published it in their web pages. This situation has been evidenced in some consulting works performed at some SMEs in Ecuador.

Besides, we have seen that relevant decisions made by their executives such as acquiring or enhancing plant's capacity, merging business units or lunching marketing campaigns are very closely tied to strategic decisions. These decisions were specifically made to outperform competition, thus we can assume that directors intentionally or at least intuitively targeted to improve their competitive position. However, minimum effort or resources were utilized to ensure the quality of their decision in strategic terms. In those cases, personal experience and intuition guided their mental maps when designing to making choices.

Although there are many tools that the state of the Art suggests to apply when formulating strategy at the beginning of the management cycle, we have evidenced through the consulting experience that they firms rarely use them in this segment.

Quiñonez (2012) asserts that competitiveness and strategic management are key elements for their continuity. In his research, the author spotlights the fact that in 
Ecuador SMEs represent $95 \%$ of production units in the country. In this sense, a study conducted by Deloitte \& Touch in 2008 revealed that Ecuadorian executives think that diminishing production costs and cheap labor are their principal source of competitive advantage. This limited vision would reduce other possibilities such as differentiation in products. In this regard, Porter (2011) asserts that this option might be useful in industries in which rivalry intensity is high. Thus, other available options may not be considered when business owners formulate their strategic position. We may add that in the last decade dollarization in this country has fueled purchasing power, especially across the middle class, and then it is very likely that these populations are tempted to consider not only costs advantages but also other factors such as quality and hedonistic intrinsic value of products or services.

Considering that a large portion of SMEs can have access to some of those tools, we can presume that they may use those tools, which can be not only effective but also simple and affordable. If we can list a set of simple tools that can be easily managed, we can assume that those that seem to be friendly and effective should be perfectly applicable.

This paper intends to research the state of the art concerning strategic analysis tools applicable to SMEs in emerging countries where competitiveness is a key factor to reach development.

We are interested not only in their application but also in the sequential order of their utilization. In fact, we recommend a set of tools through establishing the links between them by recognizing which elements can be used as connectors as demonstrated in the Attachment 1; thus, SMEs may count on a systematic process involving a possible suggested path.

In order to prove applicability of those tools we reviewed them thoroughly and then weighing them in terms of usefulness, we propose disadvantages and limitations.

The hypothesis that guides our research is that in the decision making process, SMEs in Quito, Ecuador do not use systematically strategic analysis tools, and then not only the assessment of the context in which they act, but also their competitive position may be threatened. 


\section{THEORETICAL BACKGROUND}

In the following paragraphs, we are describing the contribution of some theorist and scholars who have supported and criticized the strategic analysis tools. Our research will be focused in not only the advantages or limitations of using them, but also on the methodological resources that exist. In order to reach this goal, we have considered some of the applications of those tools and the experience applied by some researchers in different locations throughout the world.

\subsection{Porter's five forces}

An initial recommendable path might be the industry analysis approached by Porter (1985) in which the principal forces that determine profitability of a business unit can be explained in terms of its competitive position. In fact, he asserts that in those industries, which intensity is high, achieving profitability will become more difficult despite the efforts of their executives. However, this author reveals the real importance of the tool, which is recognizing the ability of the firm to react and influence over those factors.

Thus, the roots of strategy can be found in the way executives conceive them and explore different options to obtain any competitive advantages. In this sense, the author warns that value created can be captured by customers or suppliers if for instance their negotiation power is high. Similarly, the presence of substitutes or the intensity of rivalry can affect the willingness to pay for the product.

Porter (2011) suggests that this tool provides some strategic alternative options as follows:

- Firm's competitive position can be seen as the construction of entry barriers or finding a position where forces are weak.

- Exploiting changes in the industry. This can be visible at the appearance of new competitive positions.

- Reconfiguration of the industry, as a firm finds new ways to leading and directing it to new ways of competing that changing its structure.

- Acknowledgement of the main factors that affect profitability of the firm and matching with internal resources. 
Concerning SMEs, Boian (2007) suggests that forces that negatively affect the competitive position of SMEs come from a high negotiation power of suppliers. In addition, other industries may be affected by the presence or introduction of substitute products, which can be very threatening if investment in upgrading the production system is minimal.

In order to apply this tool, it is proposed an arithmetic approach in which details factors and related sub-factors. For instance, concerning the supplier's negotiation power, the author includes price level, commercial terms and product quality as sub-factors. Furthermore, it is suggested to weigh every factor according to a previous assessment of its significance.

Then, grades every sub-factor in a one to four scale according to the strength it exerts over its competitive position. If pressure is favorable it will have positive sign, otherwise, it will be negative. This grade is calculated as a factor of its relative weight, which is added to obtain a total. A positive result will show that there is a trend that competitive forces are strengthening its competitive position, while the opposite weakens it. An example of this approach is presented bellows:

Table 1: Example of competitive position analysis

\begin{tabular}{|c|c|c|c|c|c|}
\hline Factor & $\begin{array}{c}\text { Importance } \\
\text { coefficient }\end{array}$ & Sub-factors & $\begin{array}{l}\text { Sub-factor } \\
\text { coefficient }\end{array}$ & $\begin{array}{l}\text { Sub- } \\
\text { factor }\end{array}$ & Observations \\
\hline $\begin{array}{l}\text { Customer's } \\
\text { negotiation } \\
\text { power }\end{array}$ & 0.2 & $\begin{array}{ll}- & \text { Product's } \\
& \text { differentiation level } \\
\text { - } & \text { Customer's } \\
& \text { information level }\end{array}$ & 3 & $\begin{array}{l}0.2 \\
0.6\end{array}$ & Luxury brand \\
\hline $\begin{array}{l}\text { Supplier's } \\
\text { negotiation } \\
\text { power }\end{array}$ & 0.4 & $\begin{array}{ll}\text { - } & \begin{array}{l}\text { Concentration level } \\
\text { offer }\end{array}\end{array}$ & $\begin{array}{l}-3 \\
\end{array}$ & -1.2 & \\
\hline $\begin{array}{l}\text { Appearance of } \\
\text { new } \\
\text { competitors }\end{array}$ & 0.1 & \begin{tabular}{ll} 
- & \multicolumn{2}{l}{ Capitalization level } \\
- & $\begin{array}{l}\text { Access } \\
\text { distributors }\end{array}$
\end{tabular} & 3 & $\begin{array}{l}0.2 \\
0.3\end{array}$ & \\
\hline $\begin{array}{l}\text { Direct } \\
\text { competition }\end{array}$ & 0.3 & $\begin{array}{ll}- & \text { Number } \\
\text { competitors } \\
\text { - } & \text { Product's } \\
& \text { differentiation grade } \\
\end{array}$ & $\begin{array}{l}-1 \\
3\end{array}$ & $\begin{array}{l}-0.3 \\
0.9\end{array}$ & $\begin{array}{l}\text { Cutting-edge } \\
\text { technology }\end{array}$ \\
\hline & 1.0 & & & 0.7 & \\
\hline
\end{tabular}

Source: Own

As far as strategy concerns, the wider advantage acknowledged by Ormanidhi (2008) is related to the model's capacity to providing criteria and benchmarks to analyze a cluster of business units. As any other well-structured model, the smoothness of embracing complexity is another advantage worth to mention. 
Among the cons of using the model, Grant (1997) highlights the omission of competitor's reactions and its failure to guide when the speed of the industry's change is accelerated. This author insists that this model does not consider the interaction of firms, in which its limitation has been partly covered by the game theory. However, it seems that even this method has not been very effective because instead of aiming at obtaining any competitive advantage it focuses on explaining how to reach equilibrium.

Other strategists who challenge the basic axioms of this model are Hamel \& Prahalad (1989), who in their perspective challenge the classical concepts of Harvard Business School, asserting that it restricts the business capability to innovate. Besides, insists in following a "Strategic intent" which consists in an active process to allocate resources beyond the available ones.

To sum up we can add that not all firms and especially SMEs born with neither the goal of being global leaders nor the pace of change in the environment are so vertiginous in the whole spectrum of sectors to make innovation an exclusive model to adopt.

Table 2: Pros and cons of Porter's five forces analysis

\begin{tabular}{|c|c|c|c|}
\hline Description & Application & Advantages & Disadvantages \\
\hline $\begin{array}{l}\text { The acknowledgement } \\
\text { of factors in the } \\
\text { external environment } \\
\text { let the firm taking a } \\
\text { competitive position, } \\
\text { defining scope and } \\
\text { adopting its generic } \\
\text { strategy. }\end{array}$ & $\begin{array}{l}\text { To assessing the } \\
\text { capability of the firm } \\
\text { (SME) to create and hold } \\
\text { value: } \\
\text { - Higher supplier's } \\
\text { negotiation power } \\
\text { and threat of } \\
\text { substitutes. } \\
\text { - The potential } \\
\text { entrance of new } \\
\text { rivals. }\end{array}$ & $\begin{array}{l}\text { Its application let } \\
\text { identifying the issues } \\
\text { in the respective } \\
\text { industries to being } \\
\text { sustainable and the } \\
\text { ability of the firm to } \\
\text { approach them. } \\
\text { This provides } \\
\text { competitive } \\
\text { performance indicators } \\
\text { to benchmarking with } \\
\text { current and potential } \\
\text { rivals. }\end{array}$ & $\begin{array}{l}\text { The analysis may } \\
\text { be misleading when } \\
\text { the transformation } \\
\text { speed of the sector } \\
\text { is much } \\
\text { accelerated. }\end{array}$ \\
\hline
\end{tabular}

Source: Own

\subsection{PEST Analysis}

In the opinion of Ward (2005), this tool tries to explain some variables present in the external environment that have an impact on businesses and their competitiveness. Although firms rarely have the capability to manipulate them, they could assess variables to explore either opportunities or hedge against prominent threats. Its name stands an acronym for political, economic, socio-cultural and technological evolution of the business environment. 
The assessment of these variables' influence and their elements is sometimes vital to distinguish the capacity to react of firms. For instance, political and economic variables may reveal constraints for many of the actions that executives might consider as alternatives. On the other hand, social and technological variables may help discovering new markets or new ways to assisting it or improving internal processes throughout the whole value chain.

In this sense, Dess (2011) highlights that some variables specifically have some impact in some sectors such as the economic ones, in which some industries may be more sensitive to changes in main indicators such as interest rates, unemployment level or savings. For instance, interest rates may negatively affect the real State sector.

Lawrence (2012) identified interest rates and credit access constraints as the most relevant variables for SMEs in Jamaica. In his opinion, however, businesspersons have not properly approached these elements.

Concerning socio-demographic variables, lifestyles among certain population may stimulate consumption of some products while jeopardizing others. For instance, the decrease of poly-in saturated food in contrast to low-calories products.

The application of the tool that Thompson (2012) suggests is to identify changes in consumers' behavior and new possible sourcing of raw materials.

Table 3: Pros and cons of PEST analysis

\begin{tabular}{|c|c|c|c|}
\hline Description & Application & Advantages & Disadvantages \\
\hline $\begin{array}{l}\text { The analysis of the } \\
\text { business environment } \\
\text { helps assessing its } \\
\text { influence in the SMSs } \\
\text { industry and acting } \\
\text { proactively to likely } \\
\text { competitors' actions. }\end{array}$ & 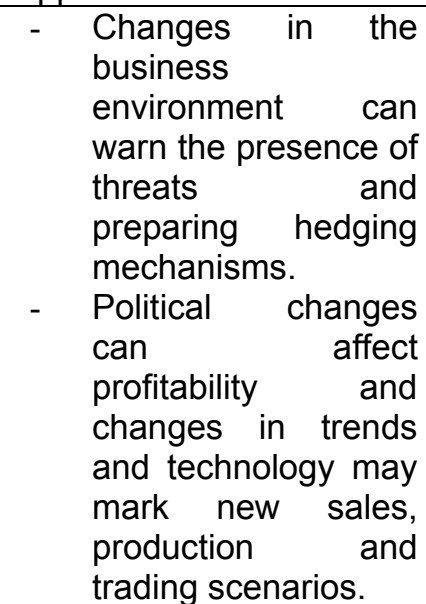 & $\begin{array}{l}\text { It may become a } \\
\text { source to define key } \\
\text { variables of the } \\
\text { environment to be } \\
\text { considered in SWOT } \\
\text { Analysis. }\end{array}$ & $\begin{array}{l}\text { PEST analysis may } \\
\text { be time consuming } \\
\text { and requires } \\
\text { researching skills to } \\
\text { gather and structure } \\
\text { information. } \\
\text { However, those } \\
\text { resources are not } \\
\text { part of the SMEs } \\
\text { characteristics. }\end{array}$ \\
\hline
\end{tabular}

Source: Own 
DOI: 10.14807/ijmp.v6i2.289

\subsection{SWOT Analysis}

This is one of the most popular tools preferred very often by its apparent simplicity. Isoherranen (2012) considers its characteristic as one of the reasons that explains its popularity. Similarly, Kormaris (2010) also asserts that this is a valuable tool because it can be jointly used with others such as PEST and Porter's five forces at either business unit level or product.

Helms (2010) acknowledge this as a powerful tool that may fully capture the efforts of a team's brainstorming. However, other authors such as Hax (1991); Ormadhini (2008) suggest that it gathers information provided by other tools such as PEST and Porter's five forces to analyze the environment and the value chain inside a firm; otherwise, the brainstorming exercise would be highly biased.

Thompson (2012) recognizes that SWOT analysis, assess the resources and competitive capabilities of the firm to exploit the best opportunities in the market and protect against threats. In addition, to distinguish an attribute as strength suggests that must satisfy two conditions:

- It should have competitive value, which means it facilitates to exploit market's opportunities and protect against threats.

- It must be rare, meaning that only few firms own it.

Besides, warns that analysts should not be limited to list variables. Instead, it should facilitate arriving to conclusions that recognize the firm's potential and it's positioning.

In order to apply this tool, Thompson (2008) suggests to list strengths in terms of key success factors in a limited number. Furthermore, grade them in a one to ten scale. The latest would be the highest score. This would let benchmark scores to main rivals and obtaining totals to evaluate them. Highest scores would let identify strengths and competitiveness. However, because related factors are different across different industries, recommends weighing this assessment. This exercise would let identify participants who have the strongest competitive positions, and who are the ones that possess relevant competitive advantages. Hence, firms might assess which offensive or defensive actions to include in their plans. 
Such as the one proposed by Zavadskas (2011), who introduced a mathematic algorithm, developed other approaches in three phases. In the first, to identify managerial capabilities uses SWOT as the starting point. In the second, establishes parameters of the problem and defines an objective function to apply either linear or integer programming. Finally, proposes a decision matrix where simulates permutations of possible outcomes. This insight provides conclusions that the managerial team may use.

Specifically in regard to SMEs Houben (1999) proposed a prototype based on the system's field. A software was utilized at ten SMEs in Belgium and was qualified as successful thanks to the inclusion of various disciplines such as Marketing, Finance, Production, Human Resources and Environment.

Another author who found this tool very applicable to SMEs was Helms (2010) and exemplified the USA and India in which approaches included both this tool and Porter's five forces. She agrees with other authors such as Grand \& Mills (2004) who think that SWOT Analysis and Value chain analysis are part of the fundamentals of strategic analysis.

Despite its popularity, the author warns that using it involves some disadvantages as follows:

- If the analysts are devoted to only listing variables, its usage might be confusing and lack coherence.

- Threats may be confused with opportunities especially when real issues are categorized as those.

- Establishing hierarchy in elements required good judgment and sometimes it may be biased.

- It fails to perform a dynamic analysis, which may reduce to a situational analysis without diagnosis capability. 
Table 4: Pros and cons of SWOT analysis

\begin{tabular}{|c|c|c|c|}
\hline Description & Application & Advantages & Disadvantages \\
\hline $\begin{array}{l}\text { SWOT analysis lets } \\
\text { firms assess its } \\
\text { competitive position } \\
\text { and then utilize their } \\
\text { strengths to take } \\
\text { advantage } \\
\text { opportunities, mitigate } \\
\text { threats and correct } \\
\text { weaknesses. }\end{array}$ & $\begin{array}{l}\text { Once the key information } \\
\text { is gathered, it becomes } \\
\text { the basis to formulate } \\
\text { strategies or to build } \\
\text { models base on } \\
\text { Mathematics or } \\
\text { knowledge management. }\end{array}$ & $\begin{array}{l}\text { - It's application } \\
\text { can provide } \\
\text { the vision of } \\
\text { every } \\
\text { functional are } \\
\text { of the firm. } \\
\text { - Executives } \\
\text { can focus on } \\
\text { key matters. }\end{array}$ & $\begin{array}{l}\text { - Listing the } \\
\text { factors per se } \\
\text { cannot lead to } \\
\text { formulate or } \\
\text { optimize } \\
\text { strategic } \\
\text { options. } \\
\text { The right } \\
\text { organization in } \\
\text { a hierarchy } \\
\text { depends on } \\
\text { the analysts' } \\
\text { expertise. }\end{array}$ \\
\hline
\end{tabular}

Source: Own

\subsection{BCG Matrix}

Decisions on allocation of resources to a certain products' portfolio are based on the position of a $2 \times 2$ matrix. The position on this matrix would suggest generic strategies to follow.

Hax (1991) reminds us that the tool created by the Boston Consulting Group in the 1960's considers two basic variables:

- Growth rate in the market

- Relative market share of the business unit or segment

These are the dimensions that split the matrix in four quadrants that define the typology of business units according to their positions. For instance, the stars which are located in the first one require intensive investment to respond to the growing demand. Similarly the question marks, which are located in the second also require big investments. However, because of the low market share, uncertainty is high and then a market research in depth becomes necessary.

Moreover, the milky cows located in the third quadrant that demonstrate high relative market share need little investment to keep the pace. In the last one, the dogs which show both low relative market share and growing, the typically recommended strategy is diminishing the investments or divesting the respective business unit.

He suggests that the strategic target positioning is expressed in terms of market share. Besides, asserts that reaches equilibrium and reduces risk when 
diversifying. Similarly, other author Kraus (2009) finds this tool very attractive in providing recommendations depending on the positioning in the matrix.

However, other authors warn that using it implies serious disadvantages as follows:

- Collis (1995) asserts that the model does not consider how much value has created every business unit.

- Lee (2007) tells that the definition of the market may be too wide or reduced. Moreover, thinks that firms and especially SMEs might find unclear or contradictory positions in the matrix if we consider different geographic sectors. Finally, omitting the cost of capital would not let obtain a financial assessment when using this model.

Hence, in the words of the latest authors mentioned, this tool may be very misleading especially if we are conscious that market share benchmarks may not be necessarily used as competitive strength indicators of firms.

Table 4: Pros and cons of the BCG Matrix

\begin{tabular}{|c|c|c|c|}
\hline Description & Application & Advantages & Disadvantages \\
\hline $\begin{array}{l}\text { Its analysis might } \\
\text { be helpful to } \\
\text { allocate resources } \\
\text { among products, } \\
\text { brands, segments } \\
\text { according to its } \\
\text { growing potential } \\
\text { and relative market } \\
\text { share. }\end{array}$ & $\begin{array}{l}\text { The position of } \\
\text { product lines in the } \\
\text { quadrants will be } \\
\text { determining } r \text { to } \\
\text { suggest generic } \\
\text { strategies. }\end{array}$ & $\begin{array}{l}\text { It's application let } \\
\text { visualize the current } \\
\text { options that generate } \\
\text { cash flow and its } \\
\text { likely evolution in the } \\
\text { future. }\end{array}$ & $\begin{array}{l}\text { - Market share may } \\
\text { not be an indicator } \\
\text { of competitiveness } \\
\text { for SMEs. } \\
\text { - Market definition } \\
\text { may not be } \\
\text { objective. } \\
\text { The assessment of } \\
\text { contribution is not } \\
\text { measured in } \\
\text { financial terms. }\end{array}$ \\
\hline
\end{tabular}

Source: Own

\subsection{Ansoff's Matrix}

Hoang (2011) asserts that the tool created by Professor Igor Ansoff in 1957 prepares the field for growing opportunities. The position in the Matrix would suggest generic strategies depending on the position of the Matrix of two rows and two columns. The matrix is typically plotted in rows representing markets (new and existing) and columns for products (new and existing).

This author recalls generic strategies according to the actual position and location of the current portfolio of products: 
- The first contains existing products in current markets and a likely strategy can be the market penetration. This one can be executed through the offer of competitive prices or marketing activities leading to increasing desirability. Although this one may be conservative, rivals' reaction may be aggressive provoking price wars.

- The second includes the development of products in existing markets, which includes the purpose of extending their products' life cycle.

- The third, involves the development of new markets using current products. To reach this goal it would be necessary to conquer new geographies, segments or distribution channels. Complementary, promotion activities may seduce audience or modifying pricing to attract different segments.

- The last one includes new products in new markets and is named diversification. When firms have reached saturation levels searching new growing opportunities might be an option.

Gianos (2013) qualifies this tool as profit exploiting one and then improving the competitive position. However, the typical usage of accounting information may be misleading.

If improving the financial performance is an objective, financial metrics and $\mathrm{DCF}^{2}$ models should be applied.

Mc Donald (1991) finds this Matrix applicable if used with other such as Porter's five forces. In particular, recommends using this technique in the process of analyzing the market structure and defining marketing goals. Similarly, Kraus (2009) considers it applicable to SMEs even though they may be recently established. The researcher finds it especially applicable to identifying new strategies and allocating resources.

On the contrary, Gunther (2011) thinks that conventional tools such as this one are not applicable to SMEs because are not realistic. He especially finds the characteristic advantage of SMEs of flexibility and flatter structure as a better condition to approaching the market and focusing on their clients. Hoang (2011)

\footnotetext{
${ }^{2}$ DCF: Discounted cash flow.
} 
concluded that the tool does not contribute to correct any biases of executives when they demonstrate extreme risk aversion.

Laszló and Ulbert (2008) researched Hungarian SMEs strategies to reach growing through the Ansoff's Matrix. His findings reveal that firms with low growing rates expectations use market penetration strategies. Conversely, high-rate growing goals used diversification strategies. Only 3\% of firms surveyed planned to renew their product-portfolios. He adds that the process of strategy creation is so inefficient that affects directly to its competitiveness. Finally, key factors that drive the success of a diversification strategy, for instance, include additional human and financial resources, collaboration, technology and organizational change.

To sum up, Ansoff's Matrix may be very useful at SMEs whichever its state is located in their life cycle. Its contribution suggest for generic marketing strategies according to the position of its portfolio elements in the Product/Market Matrix.

Table 5: Pros and cons of the Ansoff's Matrix

\begin{tabular}{|l|l|l|l|}
\hline \multicolumn{1}{|c|}{ Description } & \multicolumn{1}{|c|}{ Application } & \multicolumn{1}{c|}{ Advantages } & Disadvantages \\
\hline Its analysis can & Growing objectives will & It is a simple tool to & $\begin{array}{l}\text { Actions suggested } \\
\text { may not }\end{array}$ \\
design strategies to & determine marketing & mapping the whole \\
grow according to & strategies, and facilitate & spectrum products, & necessarily fit in \\
their current and & resource and planning & groups, clients or \\
potential markets & activities. & the proposed \\
and products. & & $\begin{array}{l}\text { quadrants and } \\
\text { biases is not } \\
\text { eliminated nits. }\end{array}$ \\
\hline
\end{tabular}

Source: Own

\subsection{The Value Chain Analysis (VCA)}

Hax (1991) finds this tool very useful because this can detail tasks, which may lead to create value in a business unit. Porter (1985) classified these activities in two groups:

- The primary ones involve physical movement of raw materials, finished goods and production of goods and services, marketing, sales and post - production services.

- The supporting activities and their essential function are not only being a base for the primary ones but also to their peers. As stated below Procurement, for instance, is a regular activity that is spread across the others. 
Porter says that it is necessary to decompose them in sub-activities, which vary in line with their industry. Some aspects to take into account in every kind of activity are as follows:

- Procurement is usually spread across the firm, and its technology is based on specific procedures to manage vendors, rules to qualify them. Furthermore, it is complemented with appropriate information system.

- Technology is next supporting activity; it embraces simple activities such as documenting the development of the product itself. Thus, it is related to the effort done to improve either the product or the processes.

- The third supporting activity is the human resources management, and supports the whole value chain. They are always present in the decision process trade-offs. For example, some firms may prefer not experienced personnel to save wages. However, cost of recruiting and training may be lost if the firm does not count on the necessary skills to keep them motivated.

- The last supporting activity in the value chain is infrastructure and includes General Management, Planning, Finance, Accounting, legal and Quality management.

Porter recommends classifying and sorting discrete activities according to the product or process flow. The basic principle is to split activities according to these criteria:

- They must have different economic contribution

- They must have an effect on differentiation

- Their costs must be significant or show a growing trend.

One of the most important contributions of VCA is the continuous searching of links across the value chain and especially about the way in which one affect the others. It is exemplified a fast food value chain, in which the schedule of the promotional campaign may influence the utilization of plant and signaled the importance of its contribution to gain competitive advantage in two ways: optimization and coordination. To help finding the links recommends to search them in the next cause effect relationships: 
- Different ways in which a function can be performed.

- The cost of direct activities can be diminished through the effort made on executing indirect activities.

- Activities performed inside the firm to reduce the effort of demonstrate or explaining the product.

In the words of Porter (1990), the basic application of this tool is the searching of activities optimization. It can be achieved through finding the links between those activities that let create trade-offs. For instance; inspection across the production process may be expensive. However, costs of customer services may be reduced.

Links between activities demand that they are coordinated when executed. Coordination may reduce timing and then cost of transactions. Besides, expensive activities are replaced by other economic ones. Another source of improving the competitive position is the chain reconfiguration through reallocation, resorting, regrouping or suppression of activities.

Another concept introduced by Porter was the value system that comprehends different value chains: the supplier, the firm, distribution channels and customers. He used the example of using the Japanese practice "Kanban" based on reducing lead times and improving the frequency of the suppliers deliver. Consequently, the benefits emerge when reducing both the transportation costs and the inventory level.

Kaplinsky (2001) suggested an alternative school called dynamic competence in which applies only some of the tool's concepts. This is based on economic growing and faster implementation than competition, which is called "upgrading".

He finds VCA very applicable to SMEs and for new producers especially if they want to introduce their products in global markets. He thinks its importance is related with systemic competitiveness, efficiency in production and comprehension of dynamic factors included in the whole value chain. In this way, he asserts that in order to improve competitiveness, inventory reduction is a key factor.

Consequently, workers would continue working in a department only if next phase require material in process. Otherwise, at next stage the production must stop. Although productivity in that unit is sacrificed, the whole system will be benefited 
because inventory levels would increase and then quality and capacity to respond would be faster.

Romero (2009) found another application to SMEs whose flexible technologies are better positioned. This can be expressed through differentiation in terms of intangibles such as technology and knowledge. However, those objectives can be opposed to the ones of big corporations or multinationals, which usually develop competences in specialized knowledge applicable to design and marketing, and to sustained innovations.

On the contrary, Senge (2000) finds that the value chain philosophy is leading to take advantage of the value created according to market conditions, and jeopardize free competition. It is evidenced when negotiation power is exerted over other firms or entry barriers are created. Thus, according to the author, innovation capability is inhibited.

Concerning VCA, we conclude that the value chain analysis is an important technique that can be applied in SMEs to assess its competitive power in both areas: costs or differentiation. Its analysis let identify additional sources of competitive advantage through improving coordination or reconfiguration.

Table 6: Pros and cons of VCA

\begin{tabular}{|c|c|c|c|}
\hline Description & Application & Advantages & Disadvantages \\
\hline $\begin{array}{l}\text { The analysis of } \\
\text { activities and sub- } \\
\text { activities and the } \\
\text { way in which they } \\
\text { execute in } \\
\text { comparison to } \\
\text { competitors can } \\
\text { identify competitive } \\
\text { advantages. }\end{array}$ & $\begin{array}{l}\text { Improving coordination } \\
\text { or reconfiguration of } \\
\text { activities in the value } \\
\text { chain are potential } \\
\text { sources of competitive } \\
\text { advantages. } \\
\text { If SMEs have access to } \\
\text { flexible technologies, } \\
\text { they can become } \\
\text { specialized vendors in } \\
\text { their value system. }\end{array}$ & $\begin{array}{l}\text { - } \text { VCA lets } \\
\text { benchmark } \\
\text { performance with } \\
\text { competitors in } \\
\text { terms of } \\
\text { efficiency. } \\
\text { VCA may identify } \\
\text { the scope of } \\
\text { entry-barriers and } \\
\text { its exploitation. }\end{array}$ & $\begin{array}{l}\text { According to Senge, } \\
\text { the VCA philosophy } \\
\text { blocks competition and } \\
\text { inhibits the capability } \\
\text { to innovate, which } \\
\text { affects the value to be } \\
\text { created for } \\
\text { communities. }\end{array}$ \\
\hline
\end{tabular}

\subsection{The Activity System Mapping (ASM)}

Morris et al., (2003) asserts that one of the requirements to achieve sustainability concerning competitive advantages is if whether or not there is internal and external fit. The first one states that consistency is a must in the configuration of activities inside a firm, while the second refers to how appropriate is that configuration with the external environment. 
To assess the first objective, mapping the activity system is an effective analytical tool. The way in which firms perform their activities can be a source of competitive advantage and remarks the importance of ASM. Then, as a successful strategy embraces the whole activity system, "the competitive advantage of a firm has its origin in the way their activities fit and how they are reinforced with each other". Porter (2011, p. 20).

This approach comprehends plotting basic competences, which show connections through highlighted lines. Main activities which have direct relation with every basic competence are also plotted along their side, and then connected through minor lines. Besides, another element identified and connected to them is every single important strategic option. As the business goes through different stages, managers made choices that are part of the strategic craft in present time. The ones, which are still present and relevant, are chosen to be graphically represented.

One of the reflections exposed by the author is that management typically is focused on basic competences, critical resources and critical success factors in a separate model. Instead, encourages looking the company integrally. In this sense, gives the example of a production line, which contains a variety of models; it produces greater value when it is combined with an inventory system that minimizes of the shortages of raw material supplying.

In addition, there are three types of fit in order of its complexity:

- The first one is a simple fit between every activity and the general strategy. This kind of fit ensures that competitive advantages are aggregated and cannot be eliminated one to each other.

- The second order of fit emerges when activities are reinforced. An example of this is BIC Corporation, which uses a low-cost strategy through a broad scope marketing approach. Fit between activities such as product design, plant configuration at low costs, large-scale procurement among others let the company reach unique competitive advantages.

- The third order is named optimization of the effort. The basic type of optimization is reached when coordination and information exchange between 
activities let eliminate the repetition of work. Higher levels of coordination include improvement in product designing to eliminate post sale services or coordination with vendors and distribution channels in regard to explicitly educate consumer in the chains instead of training the final user about the product usage.

Morris et al., (2003) asserts that SMEs at the initial stages can adopt random rules and deviate from initial models introducing inconsistent elements with the originally established. Because of the relative little experience in the market, the vision of the owner may be the only resource available at that stage.

At a mature stage, the adoption of a formal model becomes necessary. However, when firms reach their maturity when conceiving their strategy, their activity system should be adjusted by taking different paths suggested by Siggelkow (2002) such as increase, reinforcement or elimination of activities. In radical environments, the system may not face a recalibration, and then it would be necessary a reconfiguration of the system.

Table 7: Pros and cons of ASM

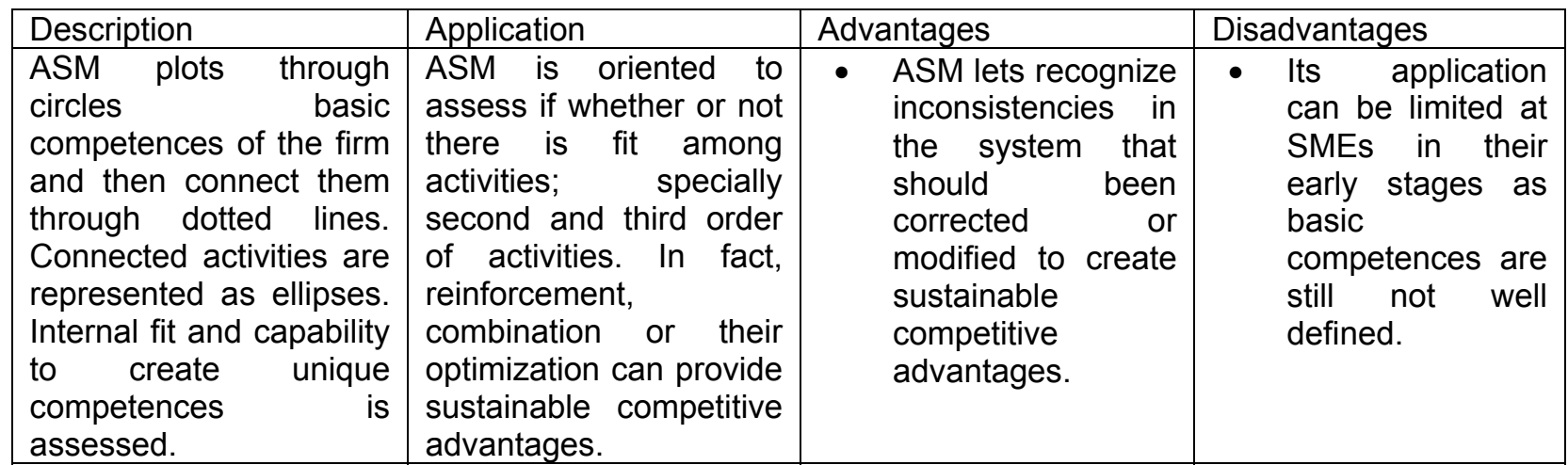

$$
\text { Source: Own }
$$

A summary of the main applications of strategic analysis tools is introduced as follows:

Table 8: Applications of strategic analysis tools

\begin{tabular}{|l|ll|}
\hline Strategic Analysis tools & & \multicolumn{1}{c|}{ Applications } \\
\hline Porter's five forces & - $\begin{array}{l}\text { Identifying relevant factors in the industry that ease reach } \\
\text { profitability and those that limit it. }\end{array}$ \\
& - \begin{tabular}{l} 
Benchmarking the competitive position with rivals \\
\hline PEST analysis
\end{tabular} & - Assessing political and legal variables to identifying \\
& $\begin{array}{l}\text { opportunities, costs and constraints in the business environment } \\
\text { to make strategic choices. }\end{array}$ \\
& - Evaluating the correlation between economic variables and \\
& - Taking advantage of socio-demographic to go in depth insights \\
\hline
\end{tabular}


DOI: 10.14807/ijmp.v6i2.289

\begin{tabular}{|l|l|}
\hline & $\begin{array}{l}\text { Over segmentation or micro-segmentation } \\
\text { Assessing the impact of technology through the value chain }\end{array}$ \\
\hline SWOT & $\begin{array}{l}\text { Applying methodology to measure competitiveness of the firm } \\
\text { compared with their competitors. }\end{array}$ \\
\hline Ansoff's Matrix & $\begin{array}{l}\text { To outline generic actions to preserve, develop or conquer } \\
\text { markets }\end{array}$ \\
\hline VCA & $\begin{array}{l}\text { Benchmarking the efficiency with competitors when using } \\
\text { resources } \\
\text { Optimizing the execution of activities through scenarios of new } \\
\text { combination or suppression of them. }\end{array}$ \\
\hline ASM & $\begin{array}{l}\text { Assessing complementarities or inconsistencies of activities } \\
\text { Evaluating requirements to suppress, reinforce, patching or } \\
\text { creating new competencies and activities } \\
\text { Evaluating the capability of firms to respond to changes in the } \\
\text { environment's configuration } \\
\text { Optimizing the activity system through simulation of its } \\
\text { reconfiguration }\end{array}$ \\
\hline
\end{tabular}

Source: Own

\section{INTERVIEWS AND INSIGHT}

We applied a semi-structured questionnaire, which was the based to obtain drivers for obtaining a wider spectrum and acquiring the most valuable information to provide additional insights on this matter.

We interviewed three prestigious consultants based in town for life and two of them agree that in general managers of SMEs in Quito do not apply strategic analysis tools. A very limited analysis is usually related to SWOT analysis, which according to their records do not surpass the $10 \%$ of their current portfolio of customers. On the other hand, a scarce $3 \%$ of their portfolio barely uses the value chain analysis, which is exclusively utilized in manufacturing businesses.

To confirm this statement, the director of the Chamber of SMEs in the province of Pichincha, in which Quito is located, asserted that firms use very unfrequently any kind of these tools. His latest management activity has been partly dedicated to prepare low cost workshops on strategic planning with emphasis on sales. Currently, this Chamber has distributed firms in sectors such as metal mechanic, real state, chemical, textile, and graphics.

Despite the fact that the Chamber has received the offer of some local colleges to analyze matters of competitiveness, participation of its members has been very limited. In the opinion of its principal, there are cultural factors that may influence on this behavior, which are related to keep strategic decisions and 
processes strictly confidential among the community of managers in these geographies.

One of the consultants advises that despite the very limited usage of these tools, there is an intuitive analysis exerted by managers. Although it not systematic, nor formal, embrace certain elements in its assessment of the environment to making decisions in the short term. Among them, rivalry intensity about competition and the presence of substitutes are often factors incorporated in their mental maps when making this kind of choices. The interviewed consultant asserted that this consideration is sometimes very helpful because although it is non-optimal, they may lead to increasing profitability in the short term.

The consultants agree in consensus that some of the lack of usage of strategic analysis tools may be attributed to some factors, which appear as follows:

- Bad managerial practices.

- Lack of knowledge on the tools and methodology.

- Vision shortage and its strengthening.

- Inadequate ability of opportunity detection

- Incongruence between long and short-term goals.

- Excessive confidence on the owner's intuition and very little demand of help to either employees or external consultants.

- Reluctance to hire external consulting for being considered either expensive or non - profit -oriented in the short term.

As specialists have mentioned, factors are structural and the shortage of tools' usage are more evident among small companies. They focus on the daily operation and seem to be obsessed with obtaining short-term results. Conversely, medium size companies show more awareness of the usefulness of tools because they perceive bigger opportunities to growing or transforming their markets.

\section{CASE ANALYSIS: INDULENTES}

Indulentes was established in 1982, by sourcing capital of two partners. They took advantage as optometrists and opened two locations by the north of the city. 
Their kindness attention and providing "free" optometric services helped to open three new establishments by the mid-nineties.

At the very beginning of the year 2000, executives put on the spot its key strength and then decided hiring high-level certified optometrists no matter their nationality. On the other hand, they decided being focused in haute-game products then becoming the main dealers of brands produced by Luxotica, the well renowned Italian factory. In this way, they could reach a high position among prestigious brands such as Rayban (USA) and Prada (Italy).

In 2010, management decided to refresh their corporative image by crossing the edge of being a visual health business to one in which esthetic is aimed at, according to trends and global fashion. Other actions such as opening shops located in some luxury malls located across the city, and acquiring five reflex-machines were taken. The installation of such lab is focused on processes of carving, bevel and especial treatment of glasses.

In 2012, they entered the corporative market by providing labor visual health conferences and "free" visual tests in the locations of their potential clients. As a complementary action, agreements with some insurance companies were reached providing certain glasses coverage.

The basic flow of company's income comes from the business retail of glasses and sun glasses. It represents the $80 \%$ of revenue, while other lines such as optometric and ophthalmologic services conform the rest.

Currently, the main vendors of the company as are follows:

\begin{tabular}{|c|c|}
\hline Vendor & \% of revenue \\
\hline Luxotica & 52.3 \\
\hline Marcolin & 10.9 \\
\hline Viva & 9.0 \\
\hline BK Frames & 8.9 \\
\hline Marchon & 6.2 \\
\hline Morel & 5.2 \\
\hline
\end{tabular}

The company has utilized the framework proposed by Porter's five competitive forces, which is summarized in the next graphic and its five forces: 
Graph 2: Competitive forces intensity in the glass sector of Ecuador

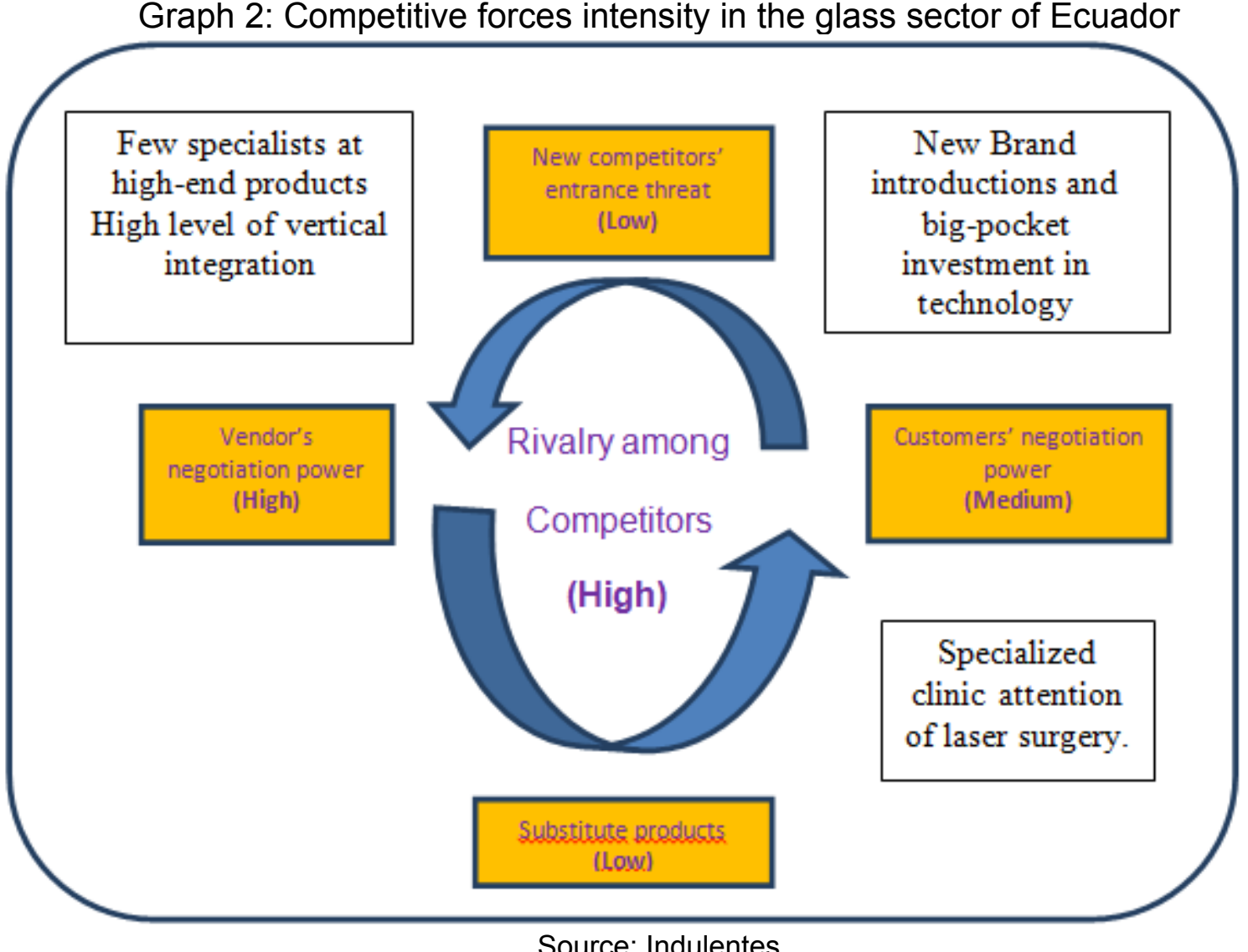

Source: Indulentes

A brief of the PEST Analysis performed by the firm's executives is summarized as follows:

Table 9: PEST Analysis

\begin{tabular}{|c|c|}
\hline POLITIC & ECONOMIC \\
\hline $\begin{array}{l}\text { - Tax policy: Ad valorem rates static. } \\
\text { - } \quad \text { Government attitude: Investment in } \\
\text { networks at the Health Ministry } \\
\text { without priority in ophthalmic health. }\end{array}$ & $\begin{array}{ll}- & \text { Economic growth. } \\
\text { - } & \text { Fixed Exchange rate through } \\
& \text { dollarization and low inflation rate. } \\
\text { - } & \text { Growing in house-hold consumption } \\
\text { - } & \text { Salaries increase. } \\
\text { - } & \text { High international prices of oil. }\end{array}$ \\
\hline SOCIAL & TECHNOLOGYCAL \\
\hline $\begin{array}{ll}\text { - } & \text { Migrant remittances growth. } \\
\text { - Being partly followers of fashion } \\
\text { trends and fully followers of } \\
\text { technology } \\
\text { - High concentration of teen agers and } \\
\text { young adults in the population } \\
\text { pyramid. } \\
\text { - Concentration of high and medium } \\
\text { class. }\end{array}$ & $\begin{array}{l}\text { - High penetration rates of internet and } \\
\text { cell phone. } \\
\text { - Technology evolution and shifts in raw } \\
\text { material usage. } \\
\text { - Innovation oriented to glasses and } \\
\text { sunglasses with higher protection } \\
\text { against UV rays. }\end{array}$ \\
\hline
\end{tabular}

Source: Indulentes

Similarly, a brief of the SWOT Analysis performed by the firm's executives is summarized as follows: 
Table 10: SWOT Analysis

\begin{tabular}{|c|c|}
\hline STRENGHTS & WEAKNESES \\
\hline $\begin{array}{ll}\text { - } & \text { Cutting-edge technology in producing } \\
\text { high definition glasses. } \\
\text { - } \quad \text { Selection of certified optometrists } \\
\text { - } \quad \text { Wide assortment of brands }\end{array}$ & $\begin{array}{l}\text { - Absence of micro-segmentation } \\
\text { activities that let know the customer's } \\
\text { perception of value. } \\
\text { Information systems do not let } \\
\text { calculate costs based on activities } \\
\text { and databases cannot identify trends } \\
\text { in consumption. }\end{array}$ \\
\hline OPORTUNITIES & THREATS \\
\hline 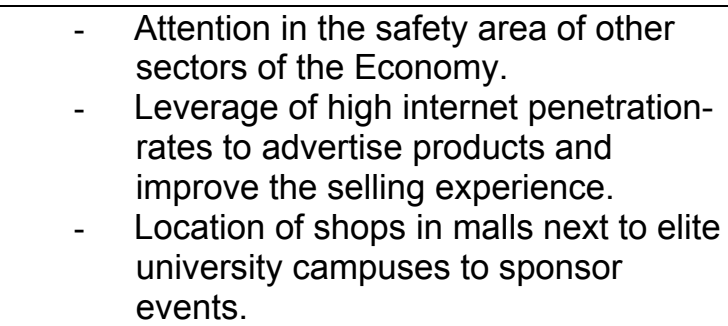 & $\begin{array}{l}\text { - Vertical integration of its main vendor } \\
\text { Luxotica exposes to being highly } \\
\text { dependent and a likely hostile } \\
\text { acquisition. } \\
\text { - Probability of increasing ad-valorem } \\
\text { and then increasing the cost of } \\
\text { products. }\end{array}$ \\
\hline
\end{tabular}

Source: Indulentes

And last but not least, executives prepared their value chain analysis. Concerning its external chain their European vendors such as Morel and Marcolin have installed distribution centers in the USA, which is an interesting opportunity to decrease freight costs in comparison to main competitors.

Concerning their internal value chain, the firm has sorted three categories considering the business activity sequence:

- Design: Designing - processes.

- Added value chain: Procurement, Inbound logistics, Operations and Outbound logistics.

- Service value chain: Installation, sales and post - sale service.

In regard to the first one, the firm will create a position of Organizational Development to achieving efficiency in their main processes. Concerning the second, the managerial team has initiated direct negotiations with vendors for speeding order's delivery. About marketing activities, executives acknowledge that despite hiring ad campaigns in radio and television, the assessment of its effectiveness in terms of coverage and image is under process.

In brief, the firm used strategic analysis tools in a very limited way not only in quantity but also in content and depth. The absence in prioritizing factors and subfactors in its Five-force analysis impeded focusing on the key ones for its sustainability. For instance, the risk of further integration of its main vendors is not 
DOI: 10.14807/ijmp.v6i2.289

appropriately assessed. In addition, there is recent legislation on matter of communication and anti-trust in force, which may affect important actions, that the company should both understand and apply some insight.

Concerning the SWOT Analysis, executives have not considered opportunities that the micro-segmentation can bring. For instance, there are endemic ophthalmologic pathologies in some provinces that may be put on the spot through alliances with specialized labs.

The utilization of an Ansoffian Matrix would have let the firm exploit in terms of profits the introduction of new brand and products, not to mention new business sectors and opening of new sales channels through the social networks on the Web.

In the value chain analysis performed, the sub-activities and its dependence with other in the chain were not established. Benchmarking the efficiency of performing key activities with competition could not be done because of the lack of metrics and an appropriate information system.

Finally, the absence of an activity system analysis thwarted the firm in perceiving the needs of introducing new core competences, strategic options and their likely connected activities.

\section{CONCLUSIONS}

Our study revealed that there are advantages and limitations when using the studied tools, but they represent a methodological contribution that could help SMEs in their assessment and implementation of strategic decisions. The main conclusions of this investigation are described bellows:

- Porter's five forces may become the initial process of the analysis and may be validated afterwards when other tools such as PEST and the Ansoffian Matrix are applied. It may have a sequential connection to other tools such as:

o Congruence and validation of conclusions provided by any product market analysis such as the Ansoffian Matrix.

o Business capacity to reinforce the competitive position through reconfiguration of its value chain or activity system. 
- The Systems field has contributed with some mathematical algorithms to strategic analytical tools such as SWOT and Porter's five forces. In this sense, research has been focused on improving efficiency by optimizing a specific objective.

- Strategic analytical tools oriented to the internal environment bring more opportunities to improve firm's competitive position because it is more likely that variables involved can be controlled or monitored. Improvement in the value chain or advantages brought by better coordination or optimization of their activity system could let them obtain better positioning.

- The majority of the tools are largely criticized in consensus for not providing a methodology to apply them dynamically. However, very few proposals to correct that limitation have been introduced. The contribution of the game theory seems to be not very useful neither focusing in strengthening the competitive position nor observing competitors game in real time.

- SWOT Analysis appears to be one of the most preferred tools. However, using only criteria of some executives or staff as the basic source of information can be highly biased.

- The most important factors that may explain the limited utilization of the described tools can be the illiteracy over their application and lassitude on assessing opportunities if they are not clearly visible.

- The application of these tools demands that SMEs have enough resource to capture the necessary information. Information systems, which are usually focused on accounting objectives, do not contribute to this kind of analysis.

- In order to detect opportunities it is keen to act in two fields. The analytical, in which these tools can help structuring information in a systematic and coherent way, and the creative, to help creating ideas coming from teams to face more complex problems.

- Strategic analytical tools can be very useful to help managers prioritizing objectives, defining options and lead decisions on main activities in functional areas. 


\section{REFERENCES}

BOIAN, N. (2007) Diagnostic of competitive position at small and medium size companies, International Conference on Economic Engineering and Manufacturing System, University of Brasov, Romania.

COLLIS, D. (1995) Competing on resources, Los Angeles. Harvard Business Review.

DESS, G. (2011). Dirección estratégica. Creando ventajas competitivas (5a Ed.), Madrid, Mc Graw Hill.

GIANOS, F. (2013) A brief introduction to Ansoffian theory and the Optimal Strategic Performance- Positioning Matrix on Small Businesses, Journal of Management Research, v. 5, n. 2, p. 108-111.

GRANT, R. (1997) Contemporary Strategy analysis (2da Ed.), Washington D.C., Georgetown University.

GUNTHER, L. (2011) Intervention Method for participatory strategy development and Implementation, A way to enhance strategic thinking and acting of SMEs,

International Journal of business and management studies, v. 1, n. 3.

HAMEL, G.; PRAHALAD, C. (1989) Strategic Intent. Harvard Business Review. HAX, A. (1991) Strategic Management. Los Angeles, Prentice Hall, 2da Ed, (p.3789).

HELMS, M. (2010).Exploring SWOT Analysis-Where are we now? A review of academic research from last decade, Dalton State College.

HOANG, P. (2011) Business \& Management, Ibid Press, 2a Ed.

HOUBEN, G. (1999) A knowledge based SWOT-Analysis system as an instrument for strategic planning in small and medium size enterprises, Decisions support system, n. 26, p. 125-135.

ISOHERRANEN, V. (2012) Strategy Analysis frameworks for strategy orientation and focus, University of Oulu, Faculty of Technology, p. 27-33.

KAPLINSKY, R. (2001) A handbook for value chain research, Available on:

http://www.prism.uct.ac.za/papers/vchnov01.pdf, Retrieved on September 30th, 2013

KORMARIS, G. (2010) A software analysis view of the software development industry, Department of information and computing sciences, Utretch University, The Netherlands.

KRAUS, S. (2009) Strategic Management and entrepreneurship: Friends or foes? International of Business Science and applied Management, n. 4.

LAWRENCE, W. (2012) Competitive analysis in SME's from Jamaica, The University of the West Indies, Jamaica.

LASZLÓ, S.; ULBERT JOZSEF (2008) The strategy formulation of the Hungarian SME Sector within the framework of the Ansoff Product/Market Matrix, International Innovation conference for cooperation and development, University of Pécs Faculty on business and economics, Pécs. p. 236-245. 
LEE, K. (2007) Limitations of conventional strategy frameworks when applied to SME's, National University of Singapore.

MC DONALD, M. (1991) Strategic Marketing Planning, A state of the Art review, Bedford, Canfield, 10th Ed.,

MORRIS, M.; SCHINDEHUTTE, M. Y.; ALLEN, J. (2003) the entrepreneur's business model: toward a unified perspective, Journal of Business Research, n. 58, p.731735)

ORMANIDHI, C. (2008) Strategic Management, An insightful and convenient approach to Firm's Analysis, University of Toronto.

PORTER, M. (2011) On Strategy, 10 must reads, Boston, Harvard Publishing Corporation.

PORTER, M. (1990) The competitive advantage of Nations, New York, The free press New York.

PORTER, M. (1985) Competitive Advantage, Creating and sustaining superior performance, Ed. Pirámide (Grupo Anaya, S.A.), 2010

QUIÑONEZ, M. (2012) Estudio de la gestión competitiva de las pequeñas y medianas empresas (Pymes) comerciales en la provincia de Esmeraldas en Ecuador. Available on: http://www.eumed.net/cursecon/ecolat/ec/2012/ Retrieved on: August $31^{\text {st }} 2013$.

ROMERO, I. (2009) Pymes y cadenas de valor globales, Implicaciones para la política industrial en economías en desarrollo, 24,57 (p.208-209).

SENGE, P. (2000) Management for $\mathbf{2} 1^{\text {st }}$ century, Boston, Harvard Business review (p.135-136).

SIGGELKOW, N. (2002) Evolution toward fit. University of Pennsylvania, n. 1, p. 136.

THOMPSON, A. (2008) Administración estratégica, México, McGraw Hill (p.102115).

THOMPSON, A. (2012) Crafting and executing Strategy, New York, McGraw Hill, 18a Ed.

WARD, D. (2005) An overview of strategy development models and the WardRivani models. European School of Economics, Milan.

ZAVADSKAS, E. (2011) Selection of construction management strategy based on the SWOT and Multi-criteria analysis. Available on:

http://www.acme.pwr.wroc.pl/repository/367/online.pdf Retrieved on: September 30th 2013. 


\section{ATTACHMENT I}

\section{PROCESS-PATH PROPOSAL}

Applying SAT to Internal and External Fit analysis

In order to present a possible path of applying SAT, we suggest the next flowdiagram to be used as an example of the methodology to be applied in order to obtain insight on Fit analysis.

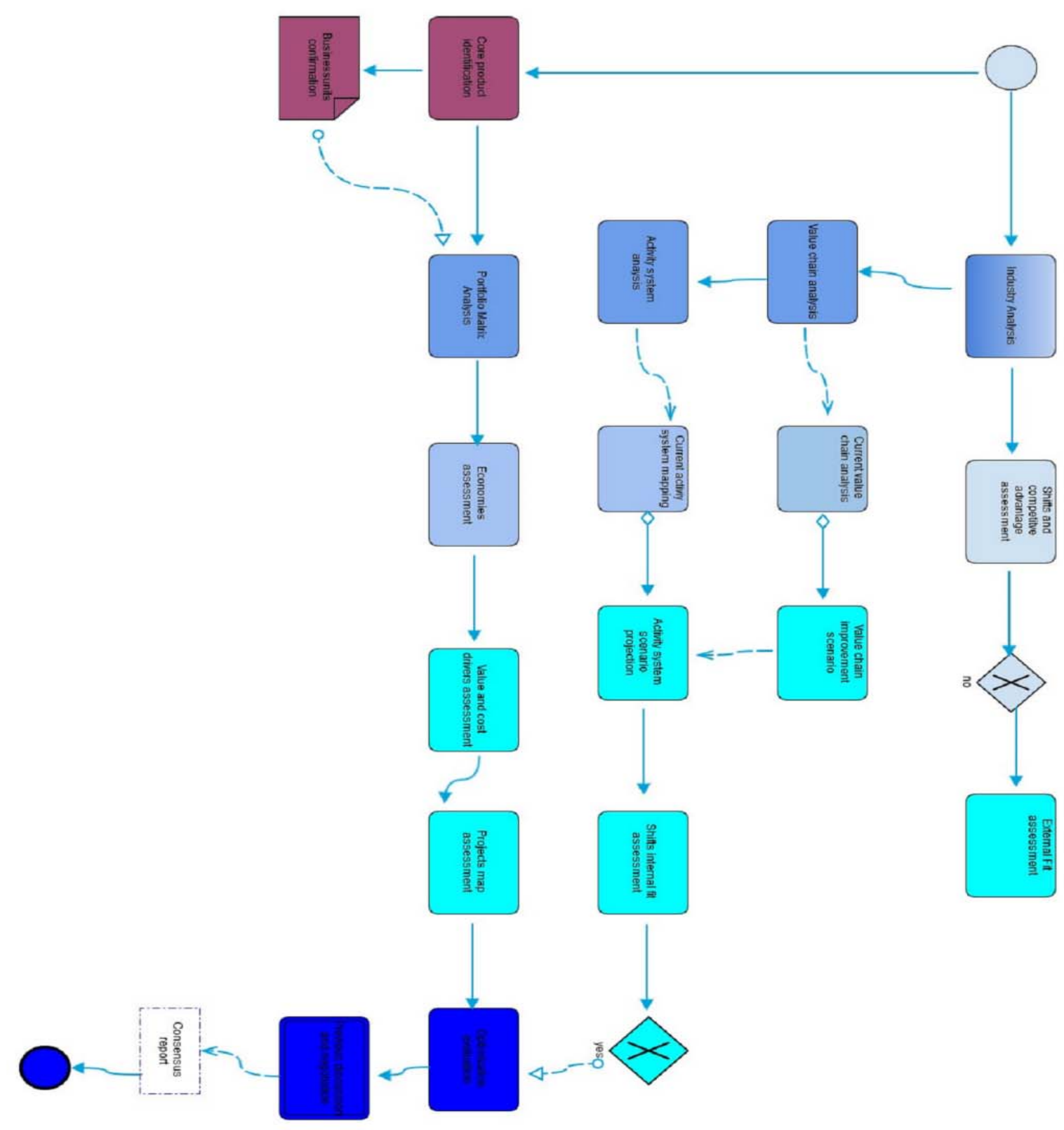

